This item was submitted to Loughborough's Research Repository by the author.

Items in Figshare are protected by copyright, with all rights reserved, unless otherwise indicated.

\title{
Surprise! Public historical geographies, user engagement and voluntarism
}

PLEASE CITE THE PUBLISHED VERSION

http://dx.doi.org/10.1111/area.12001

\section{PUBLISHER}

Blackwell Publishing $\odot$ The Author. Area $\odot$ Royal Geographical Society (with the Institute of British Geographers)

\section{VERSION}

AM (Accepted Manuscript)

LICENCE

CC BY-NC-ND 4.0

\section{REPOSITORY RECORD}

Mills, Sarah. 2019. "Surprise! Public Historical Geographies, User Engagement and Voluntarism”. figshare. https://hdl.handle.net/2134/12144. 
This item was submitted to Loughborough's Institutional Repository (https://dspace.lboro.ac.uk/) by the author and is made available under the following Creative Commons Licence conditions.

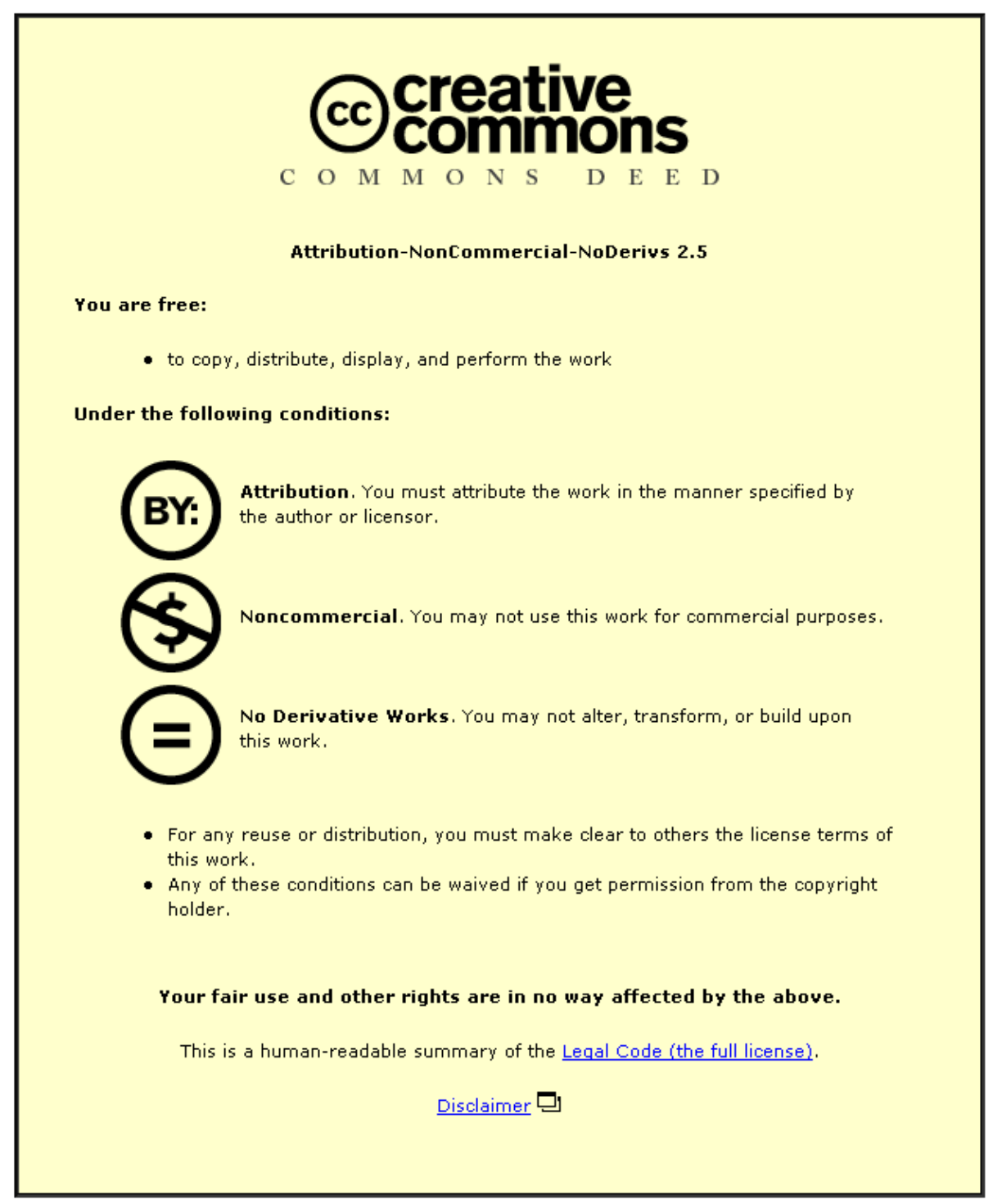

For the full text of this licence, please go to: http://creativecommons.org/licenses/by-nc-nd/2.5/ 


\title{
Surprise! Public Historical Geographies, User Engagement and Voluntarism
}

\author{
Sarah Mills, Department of Geography, Loughborough University
}

To cite this paper:

Mills, S. (2013) Surprise! Public historical geographies, user engagement and voluntarism, Area 45 (1): 16-22.

This paper aims to expand understandings of 'public geographies', not usually associated with historical geography, through considering voluntarism. It seeks to bring together debates on research practice, positionality and the 'surprise' instances of user engagement. To do so, it draws on two experiences and opportunities that emerged during my doctoral research in Wales on the cultural-historical geographies of scouting in Britain: first, curating an exhibition, and second, cataloguing and 'making' an archive collection. Both of these were voluntary collaborative activities and outside 'the research project', and yet they shaped and influenced the research process in unique and unforeseen ways. Overall, the paper uses these examples as a way into exploring geographical debates on research users, non-academic communities and the role of the researcher as a volunteer.

Key words: Wales, user engagement, archive, exhibition, voluntarism, public geographies

\section{Introduction}

This paper considers the boundaries of academic practice and draws attention to the 'surprise' instances of user engagement. In doing so, it reflects on the fluidity between research, volunteering, and everyday life. There is a growing literature within geography that advocates engaging 'public geographies’ (Fuller 2008; Fuller and Askins 2007; Fuller and Askins 2010; Hawkins et al 2011), experiments with various collaborative writing projects and non-academic 'outlets' (Mitchell 2008; mrs kinspaisby 2008; Thrift 2002) and calls for working with people rather than for them or about them (Gregory 2005; Johnson and Pratt 2010). This paper considers the surprise and unforeseen opportunities of user engagement that may emerge in the midst of research. Rather than reviewing work on disciplinary engagements with different 'publics' and geography’s reach (Harris 2011), here I consider 
the practice and politics of public historical geographies as part of a wider argument about voluntarism and its role in the research process. Indeed, framing this discussion in terms of public historical geographies may also be surprising: there is relatively little work on the engagements of historical geographers with various non-academic communities (although see Merriman 2010) and this paper aims to expand understandings of these relationships through considering voluntarism and uniquely historical themed activities.

To do so, I draw on two examples of unexpected engagement that emerged whilst undertaking my doctorate on the cultural-historical geographies of scouting in the UK: to be a curator and to create an archive. Whilst these are activities and spaces associated with historical geography, the observations in this paper about research practice, volunteering and the 'unexpected' are pertinent across the discipline. This discussion is timely and relevant: contested concepts of 'user engagement', 'non-academic communities', 'knowledge exchange’ and 'impact' are shaping research practice, design and dissemination (see Maddrell 2010; Phillips 2010; Rickinson et al 2011; Pain, Kesby, Askins 2011; Williams 2012 for examples). But how can costed and timed exercises in grants and fellowships account for the surprise, unforeseen and unexpected opportunities - of 'helping out' or ‘pitching-in'?

In exploring these questions, this paper makes two broad contributions to academic debates and geographical knowledge. First, it seeks to expand understandings of public geographies to include historical engagements and collaborations, as well as the complex and often conflicted subjectivities that emerge whilst researching and volunteering. Second, it highlights the unplanned and unforeseen examples of 'user engagement' that particular systems (for example the upcoming Research Excellence Framework in 2014 ${ }^{1}$ ) often 
conceive as pre-written into grants, and in doing so, opens up an important discussion about definitions and understandings of 'user engagement' that will be increasingly significant in the future academic landscape (on unplanned forms of participation see Kraftl and Horton 2007).

In the first section, this paper explores some of the literature and debates around 'public geographies' and 'user engagement'. It then explores two examples from my doctoral research - creating an exhibition and creating an archive - to illustrate this paper's main argument about the need to consider the role of voluntarism within public geographies to reflect on the subjectivities, spaces and sites of academic practice. There were a number of examples I could have drawn upon to illustrate this argument. On the one hand, I have engaged in small scale, perhaps even banal examples of 'public geographies' which involved contemporary scouting youth through my role as a volunteer who also does research. For example, facilitating a workshop with the Welsh Scout Council on policy development, or running activity badge nights on international scouting for Cub Scouts in Aberystwyth and Leicester. For the purpose of this paper, however, I reflect on two collaborative experiences of public historical geographies that were unplanned and emerged during the 'messy' stages of $\mathrm{PhD}$ research - voluntary activities that ran alongside fieldwork and writing. Indeed, many research projects are now framed as 'public' from the very start, with distinct research outputs for non-academic communities. This paper offers a different perspective on these debates through uniquely historical themed examples and surprises. I want to create space to reflect critically on the difficulties and challenges of expectations, demands, failures and regrets involved in 'public geographies' as a volunteer, themes discussed in the final concluding section of this paper, which also suggests future research avenues. 


\section{Public Geographies and User Engagement}

Recent reviews of work on public geographies and user engagement have demonstrated the opportunities and relevance of appropriate geographical involvement, whether relating to policy (Ward 2006), artistic and creative outputs (Driver et al 2002), issues of activism and social justice (Brown and Pickerill 2009; Chatterton 2008; Pain and Hopkins 2009) or mediabased engagement (Harris 2011). Whilst part of knowledge production and dissemination, these activities are often motivated by personal, political or pedagogical reasons - making them an interesting foci for understanding broader approaches to research, positionality, ethics and the everyday 'stuff' geographers do. Indeed, there are often difficulties between 'traditional' and 'organic' forms of practice and it is important to highlight that personal and political motivations can shape whether 'surprises' or opportunities that may emerge in the research process are taken up, embraced, ignored or rejected. It is, however, difficult to ascertain the scope and scale of geographer's involvement in various activities, hence Peter Merriman's recent call for “the establishment of a non-commercial archive of geographical engagement” (2010, 388) that he argues would also highlight “many of the 'quieter' engagements, outputs and activities of academics [that] are seldom registered beyond their immediate constituency” (2010, 387). His short observational paper provides some of the impetus for this article and its exploration of two of the 'quieter' engagements I undertook, crafting an argument about the motivations in when, where and how voluntarism is 'taken up' in research projects and everyday life.

It is not that my doctoral research used participatory research methods (Kindon, Pain and Kesby 2007; Cahill 2004; Cope 2008). Indeed, I undertook archival fieldwork that traced the 
lives of children and young people, as well as volunteers, over the centennial history of scouting in the UK - most of whom are no longer alive and research subjects with whom participatory action research was not possible. However, I felt strongly at the beginning of my research that there would be opportunities for me to engage in participatory dissemination activities and I often considered how my research could be 'useful' and 'engaging' beyond the academy, even though it dealt with 'young ghosts' (Mills 2012). Indeed, it is important to reflect on the explicit emotions of research and associated practices (Askins 2009; Brown and Pickerill 2009) and indeed "what does such recognition of the significance of emotion mean?” (Askins 2009: 11), particularly in this case around how these hopes, thoughts and imaginings unexpectedly manifest themselves in two separate projects during the early stages of my PhD. Both of these activities started with a direct request for me to 'volunteer' - first locally (to run an exhibition) and then nationally (to create an archive). I therefore want to consider how volunteering and notions of 'giving' intersects with research: running alongside, interrupting, distracting, engaging or inspiring (on geographies of voluntarism more broadly, see Baillie Smith and Laurie 2011; Milligan 2007; Hardill and Baines 2011). This paper also opens up broader questions about the researcher's identity as a volunteer (or activist, campaigner, teacher, and so on). How and where do these identities emerge and shape each other?

In now turn to the two examples to illustrate how these distinct engagements 'came about' unexpectedly, through invitations, dialogues and collaborations, and how they continue to 'appear' in both my academic and personal life, in order to illustrate this paper's argument about a more broadly defined understanding of user engagement activities and to highlight the role of surprise and the unexpected.

\footnotetext{
“Would you mind...?”: The Exhibition
} 
The first three months of my PhD in Autumn 2007 coincided with the centenary of the UK Scout Association. I was beginning my research training when an opportunity arose to commemorate that event: a mixture of celebration, critical reflection and publicity. Another adult leader at my local Scout Group in Aberystwyth in mid-Wales where I had volunteered since 2003 had the initial idea for an exhibition, but wanted someone to steer the project and lead a team of helpers. Would I help? Would I mind? The chance to be involved in a museum project was incredibly exciting and after a few planning meetings (and with permission from my supervisors) I approached Ceredigion Museum in Aberystwyth. They were keen on the idea (although wary of lack of experience) and booked a one week slot in November for a temporary, free, stand-alone exhibition in the main exhibit hall. There are a number of examples of geographers guest or co-curating exhibitions (Bressey 2002-2003, 2006-2007; Gilbert and Lister 2006; Tolia Kelly and Nesbitt 2009), often with national or London-based museums. Ceredigion Museum is a local and regional museum based in Aberystwyth, housed in a restored Edwardian Theatre, with a permanent exhibition on rural Welsh life and various temporary exhibitions on craft or photography (see Ceredigion County Council 2012). Throughout the process, they were very supportive. However, the Museum often relies on volunteers themselves and are under-resourced in several areas, reflecting the uneven landscape of museum spaces in the UK (Holmes 2003).

Time was spent writing letters and calls for exhibition items in local newspapers, websites and through networks of the Welsh Scout Council. Soon, I began to receive phone calls and would intersperse visits to the library with visits across Wales to collect loaned items - books, badges, uniforms and photographs - and to listen to people's memories of scouting in Ceredigion. This venture was unfunded, apart from small expenses covered by the Scout Group. I was aware that the exhibition had obvious ties to my $\mathrm{PhD}$ and was a chance to get a 
feel of what could be lurking in the archive when 'real' fieldwork would start, but there were different motivations at play here and indeed a distinct sense of responsibility. I wanted to help out the Scout Group and put on something special in the town, to support my friend, and arrange a trip for Cub Scouts to work on their local knowledge badge. It was a mixture, then, of being a researcher in early planning stages of a project on a related topic, and being a volunteer asked to 'run with something' and help out. However, the two positions were not separate, and as hinted already, would merge and mix in various ways.

Questions of content, representation and layout began to override the logistics as I planned the exhibition boards: What should be the balance of information on UK, Welsh and local scouting? How much should I focus on Robert Baden-Powell? Indeed, whilst the founder of the Scout Movement is often a controversial figure, he had a number of family ties to Wales and was instrumental in devolved governance to Welsh Scouting in 1925. Museum spaces and the politics and representations of exhibitions have been considered by geographers (Geoghegan 2010; Crang 2003) and I began to read around these topics whilst planning the event. I used my coffee table and carpet to practice the layout of the exhibition, printing bilingual draft description slips (with the help of my friend and colleague) and trying to envision how it would all look. I imagined the space and walking around the route a visitor would take (on exhibitions and 'flow' see Hornsey 2010). Indeed, it was not until the day of 'setting-up' that much changed: moving items, trying different cabinets and lighting options. It really was a case of 'learning by doing' as a novice and being thrown in the deep end listening to advice from staff at the Museum and collaboratively deciding with them and the small group of three helpers from the Scout Group about the look and 'feel' of the exhibition. In similar ways to my later experience of fieldwork at the archive of the Scout Association, the exhibition was not simply a 'repository' but informed contemporary practices of research 
(Mills 2012). The week of the exhibition, I visited every day and often sat in the coffee area chatting to visitors. Discussions inevitably turned to my role as a volunteer in Aberystwyth, but also the PhD I had just started. Therefore very early on in my doctoral research, I identified how entwined all of these activities were. I unexpectedly gained valuable contacts in local history and scouting circles and it provided me with an opportunity to listen and engage with local people about scouting memories.

In many ways, the exhibition was the catalyst for research ideas and other explicit academic 'benefits'. Some of the material that was lent for the exhibition I collected as 'data' (with permission from owners) and have drawn upon this material in my thesis and conference papers. Indeed, the first 'writing' of my $\mathrm{PhD}$ was the boards and description cards for the exhibition - writing for a non-academic and general audience. Surprise findings included photographs of $3^{\text {rd }}$ Aberystwyth Scout Group that leaders and the committee had not encountered before. For everyone involved in the exhibition, these photographs and other objects became enfolded back into the lives of the Scout Group: displayed in the Scout Hut, printed out for retired leaders and prompted memories that again appeared in conversations with volunteers, young people and colleagues.

However, in other ways, this project was challenging and thought-provoking. I had a number of doubts: was I, and the other helpers, really best placed to do this? We had no experience in putting together an exhibition and there were other students in Museum Studies that would have been far more qualified. I felt the pressure of delivering a useful and engaging exhibition that had room for critical reflections on the organisation. I worried about the responsibility of having items of local people's precious scout memorabilia in my living room and being entrusted with delivering an event (indeed, a different set of emotions from 
those of hope and excitement mentioned earlier in the paper). Whilst the exhibition was successful in terms of visitor numbers and feedback, once it was over, there were disappointments and retrospective reflections: if only we'd realised sooner that other groups in Wales were trying to do the same thing...if only I'd found some more evidence about Welsh language Scout groups in Ceredigion...if only we had more time, more money, more help... and so on. However, on reflection, the important thing was that the exhibition happened. Two years later, we were invited to repeat the exhibition by the Head Curator for a three-month slot with a focus on the centenary of the $1^{\text {st }}$ Aberystwyth Scout Group founded in 1909.

The original exhibition continues to 'reappear' in my research activities and thoughts. It was never intended to be part of my $\mathrm{PhD}$ project, and yet it shaped my approach to researching the historical-cultural geographies of the Scout Movement. At the time, I had not considered it as an example of 'user engagement with non-academic communities'. Indeed, this is the language we can sometimes retrospectively place on activities that have already happened that were undertaken for different motivations and, in this case, as a volunteer.

\section{“Would you mind?”: The Archive}

In this second example, I again illustrate the role of an unforeseen and surprise engagement with different research users as a volunteer and how they shaped research practices. Here, the focus is on the politics of establishing an archive collection and the role of the researcher in engaging with the 'guardians' and indeed futures of the very collections they seek to use (on archival issues and these questions more broadly, see Craven 2008). Similar to the exhibition, the cataloguing of archival material was an unexpected venture in the early stages of my $\mathrm{PhD}$, yet more unusual for a geographer to 'become' an archivist for a few weeks. 
Organisations that are registered charities often cannot afford a full-time or part-time archivist and rely on volunteers. There are signs this trend will continue with public sector cuts and the re-framing of volunteering in the current coalition government's 'Big Society' vision for the United Kingdom (Hardill and Baines 2011; North 2011).

I was approached by a member of staff at the Welsh Scout Council (WSC) to catalogue and find a 'home' for their historical material. The WSC is the organisation and governing body of scouting in Wales founded in 1925 and based in Llantwit Major, South Wales. Prior to this invitation, I had been involved in various dialogues with the WSC and their staff visiting their collection for a smaller research project and borrowing some items for the exhibition discussed in the previous section. This also highlights the interplay between various user engagement activities and how one can often lead into another.

In his overview of historical research methods, Hayden Lorimer points to examples of diverse engagements with the archival record, drawing on non-academic work to show "the creative approaches and campaigning practice employed by activist musicians and journalists that might offer methodological leads for those wishing to build bridges between the material contents of the archive and the continuing social and political life of the world outside its bounds” (2009: 264). He also points to the work of Caitlin DeSilvey (2003) and a campaign against a particular urban development that was assisted through evidence and archival records. In this section, rather than discuss how one can use material covered in dust for political activism, I consider what it means to be dust-covered (Steedman 2001). Indeed, how does getting your hands dirty (in this case - literally) with archival material impact the process of research? 
Whereas the exhibition outlined in the previous section was a collaborative project that I led and had to 'sell' to the museum, this archival project was a case of being directly invited to help with something that had an explicit connection to research material. It was something the trustees had identified as needing to be done in order to eventually relocate the archive for wider public access and practical safety concerns. In doing so, this project again assisted me as a researcher to engage with, and collect, material, as well as gain a sense of the wider processes and practices of historical research. Instead of following my own intuition about what should be in the exhibition, here I had a very specific brief and remit to complete a task.

The WSC covered the expenses of several trips to their Headquarters and I would make these trips between postgraduate teaching and research commitments. I sifted through dusty boxes, handwritten logs and word processed folders (1925-2000) to produce an electronic spreadsheet cataloguing their entire collection. Each item in 'The Back Cupboard' had to be numbered, described and re-boxed. No previous records or order (chronological or thematic) had been established and the cupboard contained diverse material. Very quickly, a pattern and rhythm of volunteering and researching emerged:

Back office. Back cupboard. Back to volunteer...

Box. Pull. Read (glance).

Type Number. Type Description. Folder. Label. Box. Repeat.

The repetition and monotony of the task meant the process became mechanical and subconscious. I learned how far away to keep the labels just in reach, where to rest my notebook and the way I could lean my chair to pull the next item from the box. Often though, things would surprise me, stop me in my tracks and I slipped into research mode: 
Back office. Back cupboard. Back to research...

Box. Pull. Read (glance). Stop. Read (carefully). Photocopy. Annotate. Scribble. Think. Type Number. Type Description. Folder. Label. Box. Repeat.

A separate pile for 'research' emerged, photocopies or photographs of things I'd 'look at later' - once the project was done and I was back in the department. At other times, I would find fantastic examples of items that were not related to my research project, but may have interested my Cub Scouts (and the second exhibition) that I was allowed to borrow:

Back office. Back cupboard. Back to volunteer...

Box. Pull. Read (glance). Stop. Enquire.

Lend item. Sign Out. Box up. Put in car.

Type Number. Type Description. On-Loan Sticker. Repeat.

When I found a 'gem' in the collection (such as the Welsh language Scouting for Boys Sgowtio I Fechgyn), I would often go and show it to the three administrative staff who worked in the office. We imagined various characters that cropped up in material, chatted about particular events (especially if it was within their period of employment) and shared anecdotes. At times, finding material relating to particularly sad events in the history of the WSC (for example, deaths of prominent leaders or Commissioners) could change the whole mood of the office. Other times, newspaper reports or amusing diary entries provided light relief (on similar conversations with others during ‘archive construction’ see Laurie 2010; Ashmore et al 2012). After a while, however, the routine and repetition of cataloguing became mechanical, especially with the number of boxes there and at some point - a thesis to 
write. In many ways then, these days could have been seen as a distraction from my $\mathrm{PhD}$ creating administrative lists and boxing material - however, I have already stated how this project was a catalyst for research ideas and shaped the research process. I also felt great pride in 'pitching in' as part of something worthwhile, despite its challenges and frustrations. Indeed, having completed the spreadsheet in 2009, at the time of writing the material still remains 'in the back cupboard' due to the ongoing politics of finding an official 'home' for it.

This example has hinted at possible conflicts and issues of positionality when researchers volunteer for different projects and become invested in the aims and direction of archive collections. Although the 'archive' and material in the back cupboard is available for individuals to access, I obviously had the support and resources of the organisation to simultaneously conduct research and ask questions whilst helping them out.

\section{Conclusion}

This paper has highlighted the role of voluntarism in the emergence and execution of public (historical) geographies with non-academic users. In doing so, it makes an argument for considering how 'surprises', and the unexpected, shape and influence research practices and the process of research. This is also part of a much broader argument for academics to consider more of what we do as influencing our research and our roles, and to highlight the various spaces where these identities emerge and shape each other. Drawing on two specific examples of an exhibition and an archive, this paper has sought to open up debate on the role of the researcher as volunteer. It is also important to state that my sense of responsibility with these engagements has not ended with the completion of my doctoral research; indeed, my current research activities have built on these relationships, collaborations and emotional attachments to these and other similar groups. Indeed, I would argue that we often put 
ourselves in research positions because of our interests, motivations and politics and that these usually align with our decisions to 'take up voluntarism' or opportunities that may present themselves. Crucially though, I argue that these can be surprising in their emergence rather than surprising in the sense of random involvement or unlikely alignments with our positionalities Here, I want to propose future directions for discussion on these topics.

First, to question and consider the role of volunteering in research more broadly. Indeed, all research is, in essence, voluntary. Although negotiated with non-voluntary elements of gatekeepers, institutional structures and so on, the ways in which time and energy spent in research design, data collection, analysis and dissemination goes beyond employment, to seep into other time-spaces of our everyday lives, suggests it is not just user engagement where ideas about voluntarism and cultures of 'giving' might be useful in critically interrogating the geographies of research, higher education and the current academic landscape. What could theoretical ideas about philanthropy (Daly 2011), for example, tell us about the ways in which people use and divide their time, motivate or prioritise?

Second, there is scope for greater discussion about the term 'users' and the contested terminology to describe activities ‘beyond the academy’. Here, I have tried to show how users are not just those involved in the research (participants) but can also be an organisation, helping them out during as well as after 'a research project', as well as the 'public' (Staeheli and Mitchell 2007), charities, young people, policy and other 'surprise' groups and individuals along the way. Furthermore, I have highlighted how the activities described in this paper supported me in my own research, complicating the ways in which we often think of user engagement as a linear activity; in this case, it was a much more collaborative experience that shaped and influenced the research process in unique and unforeseen ways. 
Finally, I would call for more support and guidance in this area for postgraduates. Whilst material and practical advice about communicating beyond the academy is starting to emerge (for example, Gardener et al 2010), there is often little in postgraduate training that indicates the unexpected surprises and opportunities that may occur in terms of user engagement, with much of the discussion perhaps targeted at more senior academics and holders of large research grants. I would definitely advocate seeking advice and support in organising or being involved in certain activities discussed in this paper, and believe there should be space to reflect critically on the difficulties and challenges involved in 'public geographies', as well as acknowledging the 'impact' they have in the lives of researchers.

\section{References}

Ashmore P, Craggs R and Neate $\mathbf{H} 2012$ Working-with: talking and sorting in personal archives Journal of Historical Geography 38 81-89

Askins K 2009 That's just what I do: Placing emotion in academic activism Emotion, Space and Society 2 4-13

Baillie Smith M and Laurie N 2011 International volunteering and development global citizenship and neoliberal professionalization today Transactions of the Institute of British Geographers 36 545-559

Bressey C 2002-2003 Before Windrush: Images of Black and Asian Figures, 1890s-1930s National Portrait Gallery, London

Bressey C 2006-2007 London, Sugar and Slavery Museum in Docklands, London

Breward C, Gilbert D and Lister J eds 2006 Swinging sixties: fashion in London and beyond 1955-1970 V\&A Publications, London

Brown G and Pickerill J 2009 Space for emotion in the spaces of activism Emotion, Space and Society 2 24-35

Cahill C 2004 Defying gravity? Raising consciousness through collective research Children's Geographies 2 273-286 
Ceredigion County Council 2012 Ceredigion Museum Website, Available at: http://www.ceredigion.gov.uk/index.cfm?articleid=197 Accessed June 2012

Chatterton P 2008 Demand the possible: journeys in changing our world as a public activistscholar Antipode 40 421-428

Cope M 2008 Becoming a scholar-advocate: participatory research with children Antipode 40 428-435

Crang M 2003 On Display: The poetics, politics and interpretation of exhibitions in Blunt A, Gruffudd P, May J, Ogborn M and Pinder D eds Cultural Geography in Practice Hodder Arnold, London 255-268

Craven L ed 2008 What are archives? Cultural and theoretical perspectives: a reader Aldershot, Ashgate

Daly S 2011 Philanthropy as an essentially contested concept Voluntas: International Journal of Voluntary and Nonprofit Organizations [onlinefirst]

DeSilvey C 2003 Cultivated histories in a Scottish allotment garden Cultural Geographies 10 442-468

Driver F, Nash C, Prendergast C and Swensen I eds 2002 Landing: eight collaborative projects between artists + geographers Department of Geography, Royal Holloway

Fuller D 2008 Public geographies: taking stock Progress in Human Geography 32 834-844

Fuller D and Askins K 2010 Public geographies II: Being organic Progress in Human Geography 34 654-667

Fuller D and Askins K 2007 The discomforting rise of “public geographies": a "public" conversation Antipode 39 579-601

Gardener R, Dodds K, Souch C and McConnell F 2010 Communicating geographical research beyond the academy: A guide for researchers, RGS (with IBG), London

Geoghegan H 2010 Museum geography: Exploring Museums, Collections and Museum Practice in the UK Geography Compass 4 1462-1476

Gregory D 2005 Geographies, publics and politics Progress in Human Geography 29 182193

Hardill I and Baines S 2011 Enterprising Care: Unpaid voluntary action in the $21^{\text {st }}$ Century Policy Press, Bristol

Harris F 2011 Getting geography into the media: understanding the dynamics of academicmedia collaboration The Geographical Journal 177 155-9

Hawkins H, Sacks S, Cook I, Rawling E, Griffiths H, Swift D, Evans J, Rothnie G, Wilson J, Williams A, Fennay K, Gordon L, Prescott H, Murphy C, Allen D, Mitchell T, 
Wheeldon R, Roberts M, Robinson G, Flaxman P, Fuller D, Lovell T, Askins K 2011

Organic Public Geographies: “Making the Connection” Antipode 43 909-926

Holmes K 2003 Volunteers in the heritage sector: a neglected audience? International Journal of Heritage Studies 9: 341-355

Johnston C and Pratt G 2010 Nanay (Mother): A testimonial play Cultural Geographies 17 123-33

Kindon S, Pain R and Kesby M eds 2007 Participatory Action Research Approaches and Methods: Connecting People, Participation and Place Routledge, London

Kraftl P and Horton J 2007 'The health event': Everyday, affective politics of participation Geoforum 38 1012-1027

Laurie N 2010 Finding yourself in the archives and doing geographies of religion Geoforum 41 165-167

Lorimer H 2009 Caught in the nick of time: archives and fieldwork in Crang M, Delyser D, Herbert S and McDowell L eds The Handbook of Qualitative Methods in Human Geography London: SAGE 248-73

Maddrell A 2010 Academic geography as terra incognita: lessons from the 'expedition debate' and another border to cross Transactions of the Institute of British Geographers 35 149-53

Merriman P 2010 Creating an archive of geographical engagement Area 42 387-390

Milligan C 2007 Geographies of Voluntarism: Mapping the Terrain Geography Compass 1 183-199

Mills S 2012 Young Ghosts: Ethical and Methodological Issues of Historical Research in Children's Geographies, Children’s Geographies 10

Mitchell K ed 2008 Practising Public Scholarship: experiences and possibilities beyond the academy Wiley Blackwell, Oxford

mrs kinspaisby 2008 Taking stock of participatory geographies: envisioning the communiversity Transactions of the Institute of British Geographers 33 292-299

North P 2011 Geographies and utopias of Cameron’s Big Society Social \& Cultural Geography 12 817-827

Pain R and Hopkins P 2009 Common Ground: a space of emotional well-being for young asylum seekers Centre for Social Justice and Community Action, Durham

Pain R, Kesby M and Askins K 2011 Geographies of impact: power, participation and potential Area 43 183-8 
Phillips R 2010 The impact agenda and geographies of curiosity Transactions of the Institute of British Geographers 35 447-52

Rickinson M, Sebba, J and Edwards A 2011 Improving Research through User Engagement Routledge, London

Staeheli L and Mitchell D 2007 Locating the public in research and practice Progress in Human Geography 31 792-811

Steedman C 2001 Dust: The Archive and Cultural History Rutgers University Press, New Brunswick

Thrift N 2002 The future of geography Geoforum 33 291-8

Tolia-Kelly D P and Nesbitt C 2009 An Archaeology of Race Exhibition Catalogue

Ward K 2006 Geography and public policy: towards public geographies Progress in Human Geography 30 495-503

Williams G 2012 The disciplining effects of impact evaluation practices: negotiating the pressures of impact within an ESRC-DFID project Transactions of the Institute of British Geographers

\footnotetext{
${ }^{1}$ The Research Excellence Framework (REF) is the system for assessing research quality in Higher Education Institutions in the UK. One aspect of which is 'impact' of research: http://www.hefce.ac.uk/research/ref/
} 